\title{
Correlated Response and Path Analysis for Different Characters in F3 Segregating Generation of Wheat (Triticum aestivum Em. Thell. L.)
}

\author{
M. Sowmya*, B. Yadav, G.M. Lal and P.K. Rai \\ Department of Genetics and Plant Breeding, Sam Higginbottom University of Agriculture, \\ Technology \& Sciences, Allahabad (U.P.) 211007, India \\ *Corresponding author
}

\section{A B S T R A C T}

\begin{tabular}{|l|}
\hline K e y w o r d s \\
Correlation \\
coefficient, \\
$\begin{array}{l}\text { F3 segregating } \\
\text { generation of wheat } \\
\text { (Triticum aestivum } \\
\text { Em. Thell. L.). }\end{array}$ \\
\hline Article Info \\
\hline $\begin{array}{l}\text { Accepted: } \\
\text { 04 July 2017 } \\
\text { Available Online: } \\
\text { 10 September } 2017\end{array}$ \\
\hline
\end{tabular}

The present investigation entitled "Correlated response and path analysis for different characters in $\mathrm{F} 3$ segregating generation of wheat (Triticum aestivum Em. Thell. L.)" was conducted in rabi 2015-16 at the Field Experimentation Centre of the Department of Genetics and Plant Breeding, SHUATS, Allahabad. The experiment was carried out in Randomized block Design (RBD) with three replications to derive Correlation coefficient, Correlated response and Direct and Indirect effects in 33 segregating population of wheat. Seed yield per spike $(0.282 *)$ and test weight $\left(0.275^{*}\right)$ showed positive significant association with seed yield per plant. Test weight (0.48) showed maximum correlated response it can be used for selection for yield improvement. Test weight (0.513), seed yield per spike (0.297), number of spikelets per spike (0.046) had showed positive direct effect on seed yield per plant.

\section{Introduction}

Wheat (Triticum aestivum Em. Thell. L.), belongs to Poaceae family, is the most important and major consumable food cereal of the world's populations including India. It is the most important staple food of about two billion people (36\% of the world population).

It is one of the most abundant sources of energy and protein. Wheat has accompanied the man since 3,000 to $4,000 \mathrm{BC}$. It has been evolved in part by nature and in part by human manipulation from its primitive form (einkoran wheat) into the present main cultivated species; bread wheat (Triticum aestivum L.) (Salem et al., 2007).
Most of the agronomic characters in crop plants are quantitative in nature. Yield is one such character that results due to the actions and interactions of various component characters.

Direct selection for grain yield could be misleading, therefore, information on the genetic variability and correlation of morphoagronomic traits with grain yield are helpful for making effective selection (Singh et al., 2016). The extent of genetic variability is of paramount importance for the improvement of a crop as greater is the genetic variability in the existing germplasm better would be the 
chances of to select superior genotypes (Burton and Devane, 1953).

Correlation studies provide knowledge of association among different characters and grain yield. The study of association among various traits is useful for breeders in selecting genotypes possessing groups of desired traits (Ali et al., 2008). The correlation coefficients become insufficient for using yield components as selection criteria to improve grain yields. It is reasonable to know whether any yield components has a direct or indirect effect on grain yield, so that selection studies can be carried out successfully (Khayatnezhad et al., 2010; Zecevic et al., 2005).

Correlated response: Two characters say $x$ and $y$, are correlated. A change in the mean of $x$ through selection will cause an associated change in the mean of $y$ also. This change in $y$ brought about through indirect selection on an associated character $x$ is known as correlated response (Singh and Chaudhary).

The path coefficient analysis provides a more realistic picture of the relationship as it considers direct as well as indirect effects of the variables by partitioning the correlation coefficients. More often correlation and path analysis using a set of genotypes is routine, but understanding the relationship in segregating generations is very important. To overcome the major threats including yield potential, incorporation of resistance to diseases and earliness, evaluation of genotypic performance of wheat segregating populations is the most important for plant breeder (Singh et al., 2016).

Correlation, correlated response and path analysis estimates between yield and other characters are useful in selecting desired plant type in designing an effective breeding programme. When change in one variable causes the change on other variable, the variables are said to be correlated. Keeping the above facts a view, the present investigation entitled "Correlation response and path analysis on different characters in $\mathrm{F}_{3}$ generation of wheat (Tricum aestivum Em. Thell. L.)" was proposed to gather information on the following objectives:

To study correlation and correlated response in $\mathrm{F}_{3}$ segregating generations.

To determine direct and indirect effects of different characters on yield.

\section{Materials and methods}

The present investigation involving 33 genotypes of bread wheat RAJ-1972×RAJ3765, HUW-32×RAJ-3077, RAJ1977×RAJ3077, GW-03-02×RAJ-3765, S GW-0302×RAJ-4026, RAJ-4037×HALNA, GW-03-02×RAJ-4037, RAJ-3705×RAJ-3077, RAJ-4026×HALNA， RAJ-4037×RAJ-4026, RAJ-4037×RAJ-3765, RAJ-1488×RAJ-4026, RAJ-4037×GW-03-02, RAJ-4026×GW-0302, RAJ-3765 $\times$ GW-03-02, HALNA $\times$ RAJ1972, RAJ-1972×RAJ-4037, HALNA $\times$ RAJ3077, HALNA $\times$ RAJ-4037, RAJ-3777×GW03-02, RAJ-3777×RAJ-1977, RAJ4026×RAJ-4037, RAJ-1972×RAJ-3777, RAJ1972×RAJ-1488, HALNA $\times$ RAJ3765, RAJ-

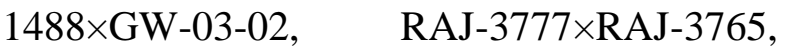
RAJ-1488×RAJ-3077, RAJ-1488×RAJ-3765, RAJ-3077×RAJ-1488, K-9162, K-307 and NW-4035 which were selected on the basis of yield performance and evaluated in randomized block design with three replications at Field Experimentation Centre of Department of Genetics and Plant Breeding, Sam Higginbottom University of Agricultural, Technology and Sciences, Allahabad during rabi 2015-16. Each segregating population was grown in two rows of 2 meter row length with spacing of 30 $(\mathrm{cm})$ and $10(\mathrm{~cm})$ between rows and plants 
respectively. Recommended package of practices and plant protection measures were followed for healthy crop growth during the season. The observations were recorded on various quantitative characters viz, Plant height $(\mathrm{cm})$, Number of tillers, Spike length $(\mathrm{cm})$, length of peduncle $(\mathrm{cm})$, Number of spikelets per spike, number of grains per spike, seed yield per spike (g), test weight (g), grain yield per plant $(\mathrm{g})$.

Ten randomly selected plants in each row of each replication observations for all the characters were recorded for all the characters under study. Correlation coefficient and path coefficient was worked out as method suggested by Al-Jibouri et al., (1958) and Dewey and Lu (1959), respectively.

\section{Results and Discussion}

Grain yield per plant showed the positive significant association with seed yield per spike $\left(0.281^{*}\right)$, test weight $\left(0.275^{*}\right)$ and it showed positive non-significant genotypic association with number of spikelets per spike (0.042), spike length (0.020) these results were in agreement with those of Subhashchandra et al., (2007) for spike length and days to maturity and for tillers per plant and grains per spike, Mondal et al., (2004) for test weight, Buller et al., (1985) for grain weight per spike and plant height. While it shows negative association with spike length $(-0.27 *)$ showed negative non-significant association with number of grains per spike ($0.18)$, plant height (-0.07).

Plant height showed positive significant genotypic association with number of spikelets per spike $\left(0.413^{* *}\right)$, peduncle length $(0.473 * *)$, and test weight $\left(0.282^{*}\right)$ it showed positive non- significant genotypic association with spike length (0.773). The correlation coefficient showed negative significant association with seed yield per plant $\left(0.411^{* *}\right)$ and it showed negative nonsignificant association with number of tillers $(-0.1930)$, number of kernels per spike ($0.172)$ seed yield per spike $(-0.176)$ whereas Akaram et al., (2008) reported that plant height was positively correlated with grain yield and Ajmal et al., (2009) positive correlation with number of tillers per plant.

Number of productive tillers per plant showed positive significant genotypic association with spike length $\left(0.479^{* *}\right)$ and it showed positive non-significant genotypic association with test weight (0.147), seed yield per spike (0.033). This was supported by the study of Singh et al., (2013). This correlated showed negative significant associated with peduncle length (-0.294), number of kernels per spike ($\left.0.816^{* *}\right)$. It showed negative non-significant association with seed yield per plant $(-0.104)$ and number of spikelets per spike $(-0.008)$

Peduncle length showed positive nonsignificant genotypic association with number of spikelets per spike (0.173), test weight (0.179) and seed yield per spike (0.162) it showed negative significant genotypic association with number of kernels per spike $\left(-0.359^{*}\right)$, seed yield per plant $\left(-0.306^{*}\right)$, it showed negative non-significant genotypic association with spike length (-0.169).

Spike length showed positive significant genotypic association with number of spikelet per spike $\left(0.476^{* *}\right)$, test weight $\left(0.391^{*}\right)$, seed yield per spike $\left(0.337^{*}\right)$, it showed positive non-significant genotypic association with number of kernels per spike (0.003) and seed yield per plant $(0.020)$.

Number of spikelet per spike positive nonsignificant genotypic association with test weight $\left(0.295^{*}\right)$, it showed negative nonsignificant genotypic association with seed yield per spike (-0.052) and seed yield per plant (-0.163). 
Number of kernels per spike positive nonsignificant genotypic association with seed yield per spike (0.004) and seed yield per plant (0.04) the correlation showed negative non-significant with test weight.

Test weight positive significant genotypic association with seed yield per plant $\left(0.275^{*}\right)$ it showed positive non-significant genotypic association with seed yield per spike (0.140).

Seed yield per spike positive significant genotypic association with seed yield per plant $\left(0.281^{*}\right)$.

\section{Correlated response}

Test weight had showed maximum correlated response $(0.48)$ followed by seed yield per spike (0.474), spike length (0.356), number of kernels per spike (0.034). While plant height $(-0.70)$, number of tillers $(-0.1773)$, peduncle length $(-0.525)$, number of spikelets per spike $(-0.2871)$ showed negative correlated response.

Test weight (0.48) showed maximum correlated response it can be used for future selection for yield improvement (Table 1).

\section{Genotypic path coefficient}

Path coefficients which are worked out from genotypic correlation coefficient are referred to as genotypic path coefficient analysis.

It splits the genotypic correlation into the measures of direct and indirect effect.

Plant height had negative direct effect (0.385) on seed yield per plant. It exhibited positive indirect effect through number of tillers (0.074) number of kernels per spike (0.066) and seed yield per spike (0.068). While other characters peduncle length (0.182), spike length (-0.029), number of spikelets per spike (-0.159), test weight (0.108 ) showed negative in direct effect on plant height.

Number of productive tillers had negative direct (-0.354) on seed yield per plant. It exhibited positive indirect effect through plant height (0.068), peduncle length (0.104), number of spikelets per spike $(0.003)$ and number of kernels per spike (0.066). While other character spike length (-0.170), test weight (-0.052) and seed yield per spike (0.021 ) showed negative indirect effect on number of productive tillers.

Peduncle length had negative direct effect (0.479 ) on seed yield per plant. It exhibited positive indirect effect through number of tillers (0.141), spike length (0.081), number of kernels per spike (0.172), while other characters plant height (-0.227), number of spikelets per spike (-0.083), test weight ($0.086)$ and seed yield per spike (-0.078) showed negative indirect effect on number of productive tillers.

Spike length had negative direct effect (0.183 ) on seed yield per plant. It exhibited positive indirect effect through peduncle length (0.031), while other characters plant height $(-0.014)$, number of tillers $(-0.088)$ number of spikelets per spike (-0.087), number of kernels per spike $(-0.0007)$, test weight (-0.071) and seed yield per spike (0.062) showed negative indirect effect on spike length.

Number of spikelets per spike had negative direct effect $(-0.045)$ on seed yield per plant. It exhibited positive indirect effect through plant height (0.081), peduncle length (0.007), spike length (0.021), number of kernels per spike (0.004) and test weight (0.013). While number of tillers (-0.0004) and seed yield per spike (-0.002) showed negative indirect effect on Number of spikelets per spike (Table 2). 
Table.1 Genotypic correlation and phenotypic correlation on seed yield for different nine quantitative characters in wheat

\begin{tabular}{|c|c|c|c|c|c|c|c|c|c|}
\hline & $\begin{array}{l}\text { Plant } \\
\text { height }\end{array}$ & $\begin{array}{l}\text { No. of } \\
\text { tillers }\end{array}$ & $\begin{array}{l}\text { Peduncle } \\
\text { length }\end{array}$ & $\begin{array}{l}\text { Spike } \\
\text { length }\end{array}$ & $\begin{array}{l}\text { No. of spikelets } \\
\text { per spike }\end{array}$ & $\begin{array}{l}\text { No. of kernels } \\
\text { per spike }\end{array}$ & Test weight & $\begin{array}{l}\text { Seed yield per } \\
\text { spike }\end{array}$ & $\begin{array}{l}\text { Seed yield per } \\
\text { plant }\end{array}$ \\
\hline Plant height & 1 & $\begin{array}{l}-0.193 \\
(0.168)\end{array}$ & $\begin{array}{l}0.473 * * \\
(0.395) * *\end{array}$ & $\begin{array}{l}0.077 \\
(0.073)\end{array}$ & $\begin{array}{l}0.414 * * \\
(0.368)^{*}\end{array}$ & $\begin{array}{l}-0.173 \\
(-0.148)\end{array}$ & $\begin{array}{l}0.283^{*} \\
(0.238)^{*}\end{array}$ & $\begin{array}{l}-0.177 \\
(-0.169)\end{array}$ & $\begin{array}{l}-0.411 * * \\
(-0.377)^{*}\end{array}$ \\
\hline No. of tillers & & 1 & $\begin{array}{l}-0.294^{*} \\
(-0.292)^{*}\end{array}$ & $\begin{array}{l}0.479 * * \\
(0.423) * *\end{array}$ & $\begin{array}{l}-0.009 \\
(-0.008)\end{array}$ & $\begin{array}{l}-0.817 * * \\
(-0.158)\end{array}$ & $\begin{array}{l}0.148 \\
(0.141)\end{array}$ & $\begin{array}{l}0.034 \\
(0.060)\end{array}$ & $\begin{array}{l}-0.104 \\
(-0.102)\end{array}$ \\
\hline Peduncle length & & & 1 & $\begin{array}{l}-0.169 \\
(-0.129)\end{array}$ & $\begin{array}{l}0.174 \\
(0.135) \\
\end{array}$ & $\begin{array}{l}-0.359 * \\
(-0.349)^{*}\end{array}$ & $\begin{array}{l}0.179 \\
(0.155)\end{array}$ & $\begin{array}{l}0.163 \\
(0.130) \\
\end{array}$ & $\begin{array}{l}-0.306^{*} \\
(-0.274)^{*}\end{array}$ \\
\hline Spike length & & & & 1 & $\begin{array}{l}0.477 * * \\
(0.424) * *\end{array}$ & $\begin{array}{l}0.004 \\
(-0.005)\end{array}$ & $\begin{array}{l}0.391 * \\
(0.345)^{*}\end{array}$ & $\begin{array}{l}0.337^{*} \\
(0.301)^{*}\end{array}$ & $\begin{array}{l}0.020 \\
(0.020)\end{array}$ \\
\hline $\begin{array}{c}\text { No. of spikelets per } \\
\text { spike }\end{array}$ & & & & & 1 & $\begin{array}{l}0.089 \\
(0.087)\end{array}$ & $\begin{array}{l}0.296^{*} \\
(0.279)^{*}\end{array}$ & $\begin{array}{l}-0.052 \\
(-0.026)\end{array}$ & $\begin{array}{l}-0.163 \\
(-0.153)\end{array}$ \\
\hline $\begin{array}{c}\text { No. of kernels per } \\
\text { spike }\end{array}$ & & & & & & 1 & $\begin{array}{l}-0.130 \\
(-0.121)\end{array}$ & $\begin{array}{l}0.004 \\
(0.012)\end{array}$ & $\begin{array}{l}0.0420 \\
(0.0465)\end{array}$ \\
\hline Test weight & & & & & & & 1 & $\begin{array}{l}0.140 \\
(0.126)\end{array}$ & $\begin{array}{l}0.275^{*} \\
(0.266)^{*}\end{array}$ \\
\hline Seed yield per spike & & & & & & & & 1 & $\begin{array}{l}0.281 * \\
(0.251)^{*}\end{array}$ \\
\hline Seed yield per plant & & & & & & & & & 1 \\
\hline
\end{tabular}

** Significant at $1 \%$ and $5 \%$ level, *Significant at $1 \%$ level.

The values in parenthesis () are phenotypic correlations.

Table.2 Genotypic path coefficient of yield attributing traits with grain yield per plant

\begin{tabular}{|c|l|l|l|l|l|l|l|}
\hline & $\begin{array}{l}\text { Plant } \\
\text { height }\end{array}$ & No. of tillers & $\begin{array}{l}\text { Peduncle } \\
\text { length }\end{array}$ & Spike length & $\begin{array}{l}\text { No. of spikelets } \\
\text { per spike }\end{array}$ & $\begin{array}{l}\text { No. of kernels } \\
\text { per spike }\end{array}$ & $\begin{array}{l}\text { Test } \\
\text { weight }\end{array}$ \\
\hline Plant height & $\mathbf{- 0 . 3 8 5}$ & 0.074 & -0.182 & -0.030 & -0.159 & 0.066 \\
per spike
\end{tabular}

Residual effect $=0.67$ 
Table.3 Phenotypic path coefficient of yield attributing traits with grain yield per plant

\begin{tabular}{|c|c|c|c|c|c|c|c|c|}
\hline & Plant height & No. of tillers & $\begin{array}{l}\text { Peduncle } \\
\text { length }\end{array}$ & $\begin{array}{l}\text { Spike } \\
\text { length }\end{array}$ & $\begin{array}{l}\text { No. of } \\
\text { spikelets per } \\
\text { spike }\end{array}$ & $\begin{array}{l}\text { No. of } \\
\text { kernels per } \\
\text { spike }\end{array}$ & Test weight & $\begin{array}{l}\text { Seed yield } \\
\text { per spike }\end{array}$ \\
\hline Plant height & -0.349 & 0.059 & $-0 . .138$ & -0.025 & -0.128 & 0.052 & -0.083 & 0.059 \\
\hline No. of tillers & 0.058 & -0.348 & 0.102 & -0.147 & -0.003 & 0.055 & -0.049 & -0.020 \\
\hline $\begin{array}{l}\text { Peduncle } \\
\text { length }\end{array}$ & -0.152 & 0.113 & -0.386 & 0.050 & -0.052 & 0.135 & -0.059 & -0.050 \\
\hline Spike length & -0.004 & -0.024 & 0.007 & -0.057 & -0.024 & 0.0003 & -0.019 & -0.017 \\
\hline $\begin{array}{c}\text { No. of } \\
\text { spikelets per } \\
\text { spike }\end{array}$ & -0.019 & -0.0004 & -0.007 & -0.023 & -0.053 & -0.005 & -0.014 & 0.001 \\
\hline $\begin{array}{l}\text { No. of } \\
\text { kernels per } \\
\text { spike }\end{array}$ & 0.021 & 0.022 & 0.048 & 0.0007 & -0.012 & -0.139 & 0.017 & -0.001 \\
\hline Test weight & 0.107 & 0.063 & 0.069 & 0.154 & 0.125 & -0.054 & 0.447 & 0.057 \\
\hline $\begin{array}{l}\text { Seed yield } \\
\text { per spike }\end{array}$ & -0.038 & 0.014 & 0.029 & 0.068 & -0.006 & 0.003 & 0.028 & 0.225 \\
\hline
\end{tabular}

Residual effect $=0.74$ 
Number of kernels per spike had negative direct effect $(-0.201)$ on seed yield per plant. It exhibited positive indirect effect through plant height (0.034), number of tillers (0.037), peduncle length (0.072) and test weight (0.072). While spike length (-0.0007), number of spikelet's per spike (-0.017) and seed yield per spike $(-0.0009)$ showed negative indirect effect on number of kernels per spike.

Test weight had positive direct effect (0.513) on seed yield per plant. It exhibited positive indirect effect through plant height (0.145), number of tillers (0.075), peduncle length (0.092), spike length (0.200), number of spikelets per spike (0.151) and seed yield per spike (0.072). While number of kernels per spike (-0.066) had showed negative indirect effect on test weight.

Seed yield per spike had positive direct effect (0.296) on seed yield per plant. It exhibited positive indirect effect through number of tillers (0.010), peduncle length (0.048), spike length (0.100), number of kernels per spike (0.001) and test weight (0.041). While plant height (-0.052) and number of spikelets per spike (-0.015) had showed negative indirect effect on seed yield per spike.

\section{Phenotypic path coefficient analysis}

Plant height had negative direct effect (0.349 ) on seed yield per plant. It exhibited positive indirect effect through number of tillers (0.059), number of kernels per spike (0.051) and seed yield per spike (0.059). While peduncle length (-0.138), spike length (0.025), number of spikelets per spike ($0.128)$ and test weight $(-0.083)$ negative indirect effect on plant height.

Number of tillers had negative direct effect (0.348) on seed yield per plant. It exhibited positive indirect effect through plant height (0.0587), peduncle length (0.101) and number of kernels per spike (0.054). While spike length (-0.141), number of spikelets per spike $(-0.002)$, test weight $(-0.049)$, seed yield per spike (-0.020) showed negative indirect effect on number of tillers.

Peduncle length had negative direct effect (0.385) on seed yield per plant. It exhibited positive indirect effect through number of tillers (0.112), spike length (0.050), number of kernels per spike (0.134). While plant height (-0.152), number of spikelets per spike $(-0.051)$, test weight $(-0.059)$ and see yield per spike (-0.050) showed negative indirect effect on peduncle length.

Spike length had negative direct effect (0.057) on seed yield per plant. It exhibited positive indirect effect peduncle length (0.007), number of kernels per spike (0.003). While plant height $(-0.004)$, number of tillers $(-0.024)$, number of spikelets per spike ($0.024)$, test weight (-0.019), and seed yield per spike $(-0.017)$ showed negative indirect effect on spike length.

Number of spikelets per spike had negative direct effect $(-0.057)$ on seed yield per plant. It exhibited positive indirect effect on seed yield per spike (0.001).

While plant height (-0.019), number of tillers $(-0.0004)$, peduncle length (-0.007), spike length $(-0.007)$, number of kernels per spike ($0.004)$ and test weight (-0.014) showed negative indirect effect on spike length.

Number of kernels per spike had negative direct effect $(-0.138)$ on seed yield per plant. It exhibited positive indirect effect on plant height (0.020), number of tillers (0.021), peduncle length (0.048), spike length $(0.0007)$ and test weight (0.016). While number of spikelets per spike (-0.012) and seed yield per spike (-0.002) had showed negative indirect effect on number of kernels per spike (Table 3 ). Test weight had positive direct effect $(0.447)$ on seed yield per plant. It exhibited 
positive indirect effect on plant height (0.106), number of tillers (0.063), peduncle length (0.069), spike length (0.154), number of spikelets per spike (0.124) and seed yield per spike (0.056). While number of kernels per spike (-0.054) had showed negative indirect effect on test weight.

Seed yield per spike had positive direct effect (0.224) on seed yield per plant. It exhibited positive indirect effect on number of tillers (0.013), peduncle length (0.029), spike length (0.067), number of kernels per spike (0.002) and test weight (0.028). While number of spikelets per spike (-0.005) had showed negative indirect effect on seed yield per plant.

Hence it can be concluded that in wheat, high heritability coupled with moderate genetic advance were observed for seed yield per plant, test weight, plant height.

Hence, these parameters could be used as selection criteria to obtain better segregates.

Correlation revealed that grain yield per plant showed the positive significant association with seed yield per spike $\left(0.281^{*}\right)$, test weight $\left(0.275^{*}\right)$ at both genotypic and phenotypic level.

Path coefficient revealed that test weight (0.513) had genotypic positive direct effect on seed yield per plant.

Seed yield per spike (0.296) and number of spikelets per spike had positive direct effect on seed yield per plant at both genotypic and phenotypic level.

Test weight (0.48) showed maximum correlated response it can be used for future selection for yield improvement.

\section{References}

Ajmal, S.U., Zakir, N. and Mujahid, M.Y. 2009. Estimation of genetic parameters and character association in wheat Journal of Agricultural Biological Science, 1(1): 15-18.

Akram, Z., Ajmal, S.U. and Muhammad M. 2008. Estimation of correlation coefficient among some yield parameters of wheat under rainfed conditions. Pakistan Journal of Botany 40 (4): 1777-1781

Ali, Y., Atta, B.M., Javed, A., Monneveux and, P. and Lateef, Z. 2008. Genetic variability, association and diversity studies in wheat (Triticum aestivum L.) germplasm, Pakistan Journal of Botany., 40 (5): 2087-2097.

Al-Jibouri, Miller, R.A., and Robinson, H.P. 1958. Genotypic and environmental variation and covariance in an upland cotton crosses of inter specific origin. Agronomy Journal 50:133.

Bhullar, G.S., et al., 1985. Genetics Agriculture 39: 1-10.

Burton, F.W., and Devane E.H. 1952. Estimating heritability in tall fescues (Tevisia araundica) from replicated clonal natural materials. Agronomy Journal 45:171-181.

Kahrizi, D., Kianoosh C., Mehdi K., Reza M. and Ebadi, A. 2010. Heritability and genetic gain of some morphophysiological variables of durum wheat (Triticum turgidum var. durum). African Journal of Biotechnology, Vol. 9 (30), pp. 4687-4691.

Mondal, S. K., and Mondal M. 2004. Genotypic variability and correlation studies in bread wheat at rainfed condition. Environment Ecology 9: 377382.

Panse, V.G., and Sukhatme, R.V. 1995. Statistical methods for Agricultural Workers, Indian Council for Agricultural Research, New Delhi, India. 
Salem, K. F. M., El-Zanaty, A.M. and Esmail, R.M. 2008. Assessing wheat (Triticum aestivumL.) genetic diversity using morphological characters and microsatellite markers. World Journal of Agriculture Science, 4 (5): 538-544.

Singh, K., M.S. Punia and Singh V. 2016. Inter-relationship between grain yield and its component characters in $\mathrm{f} 2$ generation of bread wheat (Triticum aestivum 1). International Journal of Current Advanced Research. 5(4): 749751.

Singh, R. K., and Chaudhary B. D. 1979. Biometrical methods in quantitative genetics analysis. Kalyani publishers:
Ludhiyana.

Subhashchandra, B., Lohithaswa, H.C., Desai, S.A., Hanchinal, R.R., Kalappanavar, I.K., Math, K.K. and Salimath P.M. 2007. Assessment of genetic variability and relationship between genetic diversity and Transgressive segregation in tetraploid wheat. Karnataka Journal of Agriculture Science, 22 (1):36-38.

Zecevic, V., Boskovic, J., Dimitrijevic, M. and Petrovic, S. 2005. Genetic and phenotypic variability of yield components in wheat (Triticum aestivum L.) Bulgarian Journal of Agriculture Science, 16: 422-428

\section{How to cite this article:}

Sowmya, M., B. Yadav, G.M. Lal and Rai, P.K. 2017. Correlated Response and Path Analysis for Different Characters in F3 Segregating Generation of Wheat (Triticum aestivum Em. Thell. L.). Int.J.Curr.Microbiol.App.Sci. 6(9): 166-174. doi: https://doi.org/10.20546/ijcmas.2017.609.021 